\title{
STUDI PATOLOGI BIROKRASI DALAM PELAYANAN ADMINISTRASI KEPENDUDUKAN DI KANTOR KECAMATAN JEKAN RAYA KOTA PALANGKA RAYA
}

\author{
Bureaucratic Pathology Study In Administrative Services Of The Population In Jekan Raya District Office Of \\ Palangka Raya City
}

\section{Nurhasanah* \\ Yusnalia}

Universitas Muhammadiyah

Palangkaraya, Palangka Raya,

Central Kalimantan, Indonesia

email:

nurhasanah@umpalangkaraya.ac.id

\section{Kata Kunci:}

Patalogi

Birokrasi

Pelayanan

Administrasi

Kependudukan

\section{Keywords: \\ Pathology \\ Bureaucracy \\ Service \\ Administration \\ Population}

\section{Accepted \\ January 2019}

\section{Published}

April 2019

\begin{abstract}
Abstrak
Tujuan penelitian ini adalah untuk mengetahui tentang Studi Patologi Birokrasi Dalam Pelayanan Administrasi Kependudukan Di Kantor Kecamatan Jekan Raya. Metode yang digunakan dalam penelitian ini adalah kualitatif. Adapun data primer dalam penelitian ini sebagai informannya adalah pegawai yang memberikan pelayanan dan masyarakat di Kantor Kecamatan Jekan Raya. Data sekunder dari bahan - bahan, baik berupa buku - buku, artikel, karya ilmiah, surat kabar, dan serta jurnal ilmiah.
\end{abstract}

Berdasarkan hasil penelitian mengenai Patologi birokrasi yang nampak di kantor Kecamatan Jekan Raya dilihat dari keluhan beberapa masyarakat di Kantor Kecamatan Jekan Raya masih terdapat pelayanan yang berbelit-belit dan eksistensi birokrasi juga masih sangat rendah. Agar Patologi Birokrasi dapat di atasi dengan terstruktur di Kecamatan Jekan Raya maka yang harus dilakukan oleh pihak Kecamatan Jekan Raya yaitu untuk budaya melayani rendah harus melakukan pelayanan publik berkualitas, dimana pola penyelenggaraan pelayanan publik dari yang semula berorientasi pemerintah sebagai penyedia menjadi pelayanan yang berorientasi kepada kebutuhan masyarakat sebagai pengguna.

Saran Perlunya perbaikan pelayanan administrasi kependudukan untuk meningkatkan pelayanan yang optimal kepada masyarakat, seperti upaya penambahan sarana dan prasarana, sebaiknya pihak Pemerintah Kecamatan Jekan Raya dapat menyebarluaskan brosur tentang Standar Operasional Pelayanan agar masyarakat mengetahui prosedur pengurusannya, Pemerintah Kecamatan Jekan Raya dapat memberikan informasi kepada masyarakat untuk menyampaikan atau memberikan surat apabila ada keluhan-keluhan di kotak/loket yang telah disediakan. 


\section{PENDAHULUAN}

Birokrasi di kalangan masyarakat dipahami sebagai sebuah organisasi yang melayani masyarakat dengan stereotipe yang negatif antara lain, yaitu proses pengurusan dokumen yang berbelit-belit, tidak ramah, tidak adil, tidak transparan, mempersulit dan sebagainya. Tidak salah masyarakat menggambarkan birokrasi dengan hal-hal seperti itu karena memang pengalaman-pengalaman yang tidak mengenakkan yang dialami secara langsung oleh masyarakat seperti itu, misalnya saat pembuatan KTP, akte kelahiran, mengurus sertifikat tanah, membuat paspor, memungut retribusi, dan sebagainya.

Pada era keterbukaan saat ini, keberadaan Birokrasi yang semacam itu tidak relevan lagi untuk dipertahankan. Birokrasi bukan lagi institusi yang tidak tersentuh oleh koreksi dan kritik dari pihak luar. Kebutuhan untuk memenuhi tuntutan masyarakat akan kesempurnaan layanan public yang berkualitas merupakan keharusan. Di sisi lain, berkembanya isu demokratisasi memperkuat posisi masyarakat untuk lebih berani menuntut hak-hak mereka terhadap pelayanan birokrasi.

Praktek-praktek negative yang sering dijumpai di lingkungan birokrasi pemerintah pada umumnya, seperti prosedur pelayanan yang berbelit-belit, sering terlihat banyak file yang berserakan, banyak surat yang terlambat sampai di alamat, dokumen-dokumen kurang terjaga, beban kerja tidak merata yang tertumpuk pada seseorang tertentu, suasana kerja yang kurang menyenangkan bahkan mungkin sampai terjadi adanya kemacetan-kemacetan dalam suatu tugas karena kurangnya disiplin aparatur birokrasi pemerintah, kurang memiliki managerial skill, kemampuan, ketrampilan, tidak memiliki rasa tanggung jawab serta kering dari konsep, inisiatif maupun daya kreativitas serta dalam memberikan pelayanan kepada masyarakat yang tidak memuaskan adalah sebagai sebagian penyakit yang diderita oleh suatu birokrasi.
Fenomena empiris yang kita jumpai menunjukan bahwa kecenderungannya tidak ada birokrasi yang betul-betul bebas dari berbagai "penyakit birokrasi". Birokrasi di manapun tidak ada yang kebal dari penyakit birokrasi yang tentunya sangat bervariasi, dan dirasakan sangat sulit untuk dapat menyembuhkan penyakit tersebut. Hal ini adalah sebagai suatu tantangan dan sekaligus tuntutan bagi birokrasi pemerintah kedepan. Tantangan yang harus dihadapi bukan hanya oleh birokrasi pemerintah yang kemungkinan menderita penyakit birokrasi seperti gaya managerial para pejabat, kurangnya pengetahuan dan keterampilan para petugas pelaksana, melanggar norma-norma hukum dan peraturan yang berlaku dan lain-lain akan tetapi tantangan juga dari seluruh masyarakat yang mengalami perubahan dalam berbagai bidang, politik, ekonomi, ilmu pengetahuan, teknologi dan sosial. Ke depan tuntutan masyarakat akan semakin meningkat kepada birokrasi agar semakin terbuka, transparan, makin produktif dan mampu memberikan dan meningkatkan mutu pelayanannya. Dalam situasi yang demikian, maka kinerja birokrasi aparatur negara harus benar-benar bertindak demi kepentingan bangsa dan negara dan agar dalam menyelenggarakan fungsinya, birokrasi berpegang pada berbagai peraturan perundang-undangan yang berlaku.

Kantor Kecamatan Jekan Raya memberikan pelayanan administrasi publik khususnya yang berkaitan dengan perijinan dan penerbitan, Kartu Keluarga, Surat Keterangan Kematian, Kartu Tanda Penduduk, Surat Tanah / Ahli Waris, dan sebagainya dituntut bekerja secara professional serta mampu secara cepat merespon aspirasi, tuntutan publik dan perubahan lingkungan lainnya dengan memberikan pelayanan publik yang berorientasi lebih kepada masyarakat daripada kepada atasan seperti yang terjadi selama ini dalam lingkungan birokrasi publik.

Dalam memberikan pelayanan kepada masyarakat, para pegawai masih belum dapat dikatakan 
profesional. Terdapat kesan bahwa masyarakat yang membutuhkan pelayanan merasa dibiarkan begitu saja dan kurang mendapatkan perhatian. Masyarakat harus bertanya terlebih dahulu untuk meminta pelayanan, tak jarang pula masyarakat harus kecewa karena respon yang diberikan petugas pelayanan tidak cukup memuaskan. Ketidakpuasan masyarakat mendapatkan pelayanan di Kantor Kecamatan Jekan Raya, tak lepas dari sikap Birokrat sebagai abdi Negara pemberi layanan itu sendiri. Tindakan-tindakan yang tidak semestinya dan dapat dikategorikan sebagai patologi birokrasi ditengarai merupakan pemicu dalam pemberian pelayanan publik yang kurang professional ini.

\section{METODOLOGI}

Penelitian ini menggunakan metode penelitian kualitatif. Menurut Borg dan Gall dalam Sugiyono (2012) Metode Penelitian Kualitatif sering disebut metode penelitian yang sering disebut metode penelitian naturalistik karena penelitiannya dikondisi yang alamiah. Dalam penelitian Kualitatif instrumennya adalah orang, yaitu peneliti itu sendiri. Untuk dapat menjadi instrumen, maka peneliti harus memiliki bekal teori dan wawasan yang luas, sehingga mampu bertanya, menganalisis, memotret, dan mengkonstruksi situasi sosial yang diteliti menjadi lebih jelas dan bermakna.

Alasan peneliti memilih metode kualitatif dikarenakan "penelitian yang dilakukan dengan menggunakan setting alami yang bersifat, menekankan pada proses menggunakan pendekatan induktif dan memberikan perhatian kepada makna. Metode penelitian kualitatif dipergunakan dengan cara melakukan pengumpulan data primer secara langsung di lapangan, dengan cara mewawancarai seluruh pelaku utama dalam proses kebijakan secara mendalam, dilakukan pengecekan antar narasumber, dan dilakukan observasi langsung interaksi para pelaku didalam kehidupan” (Riant Nugroho, 20I3).

\section{HASIL DAN PEMBAHASAN}

Patologi birokrasi yang nampak di kantor Kecamatan Jekan Raya dilihat dari keluhan beberapa masyarakat di Kantor Kecamatan Jekan Raya masih terdapat pelayanan yang berbelit-belit dan eksistensi birokrasi juga masih sangat rendah. Agar Patologi Birokrasi dapat di atasi dengan terstruktur di Kecamatan Jekan Raya maka yang harus dilakukan oleh pihak Kecamatan Jekan Raya yaitu untuk budaya melayani rendah harus melakukan pelayanan publik berkualitas, dimana pola penyelenggaraan pelayanan publik dari yang semula berorientasi pemerintah sebagai penyedia menjadi pelayanan yang berorientasi kepada kebutuhan masyarakat sebagai pengguna. Dengan begitu, tak ada pintu masuk alternatif untuk memulai perbaikan pelayanan publik selain sesegera mungkin mendengarkan suara publik itu sendiri. Inilah yang akan menjadi jalan bagi peningkatan partisipasi masyarakat di bidang pelayanan publik.

Adapun langkah-langkah strategis yang kiranya dapat diambil antara lain : langkah pertama, menempatkan para birokrat yang sudah terlalu lama berkuasa berkecimpung di dalam urusan pelayanan ke posisi yang lain (tour of duty). Baik itu rotasi horizontal ataupun promosi vertikal. Langkah kedua, yakni antisipasi sedini mungkin mengenalkan teknologi informasi sehingga dapat memudahkan dalam pelayanan publik.

Menghindarkan pegawai dari interaksi/transaksi uang cash antara pelanggan dan pelayan, diasumsikan bahwa semakin sering seseorang mengadakan kontak langsung dengan uang tunai semakin besar pula kesempatan orang itu untuk mengadakan KKN. Walaupun secara eksplisit diterangkan biaya serta waktu yang diperlukan untuk menyelesaikan proses pelayanan, akan tetapi praktik di lapangan akan berbicara lain. Hal seperti ini dapat disiasati dengan menyediakan mesin. Yaitu setiap formulir aplikasi permohonan pelayanan hanya butuh 
sehelai "perangko" ataupun "kupon" bertuliskan besaran biaya yang dibutuhkan untuk proses penyelesaiannya. Hal ini membawa konsekuensi logis bahwa seseorang yang bertugas melayani pelanggan tidak akan disibukkan atau direpotkan dengan urusan uang tunai di sekitar loket mereka. Mereka hanya akan berkonsentrasi di seputaran urusan administrasi persuratan saja, tidak ada yang lain. Cara lain dapat berupa transfer uang di bank dengan sistem online dengan mengadakan kerja sama antara pihak penyedia layanan (pemerintah daerah) dengan pihak bank.

Bila ditinjau dari sudut pandang pengguna jasa pelayanan, yaitu dengan memperkenalkan budaya antre yang tersistematis melalui pengadaan mesin antre (queuing machine). Kenapa budaya antre? Karena masyarakat Indonesia pada umumnya masih belum menganggap antre sebagai pola atau gaya hidup yang efektif. Sistem ini telah banyak diaplikasikan di instansi-instansi swasta dan hasilnya-pun cukup efektif untuk menciptakan suasana yang tertib dan kondusif.

Sementara berkenaan dari pihak birokrat sendiri sebagai penyedia monopoli pelayanan publik, sebagai wujud pertanggungjawaban langsung (direct responsibility) kepada pengguna jasa layanan, alangkah lebih baiknya apabila di luar loket pelayanan dipasang nama petugas pelayanan yang bertugas pada hari itu untuk memudahkan apabila terjadi ketidakpuasan pelanggan kepada penyedia jasa layanan akan langsung dapat dicatat nama petugasnya dan segera bisa ditindaklanjuti.

Dengan demikian, pada saatnya nanti akan menghasilkan pembagian beban kerja yang baik dan dapat mendorong kreatifitas dan produktivitas aparatur, selain itu efektifitas kinerja aparatur akan secara bertahap dapat ditingkatkan. Dengan peningkatan efektivitas kinerja ini akan berdampak pada peningkatan pelayanan pada masyarakat dan ketepatan waktu penyelesaian pembangunan. Semoga semua ini menjadi sebuah inspirasi bagi kebijakan pemerintah dalam menentukan kebijakan-kebijakan yang berkaitan dengan birokrasi pelayanan publik khususnya di Pemerintah Kecamatan Jekan Raya.

Kecamatan Jekan Raya harus melakukan paradigma pelayanan publik sifatnya sentralistik ke pelayanan yang lebih memberikan fokus pada pengelolaan yang berorientasi kepuasan pelanggan (customer-driven government) dengan ciri-ciri: (a) lebih memfokuskan diri pada fungsi pengaturan melalui berbagai kebijakan yang memfasilitasi berkembangnya kondisi kondusif bagi kegiatan pelayanan kepada masyarakat, (b) lebih memfokuskan diri pada pemberdayaan masyarakat sehingga masyarakat mempunyai rasa memiliki yang tinggi terhadap fasilitas-fasilitas pelayanan yang telah dibangun bersama, (c) menerapkan sistem kompetisi dalam hal penyediaan pelayanan publik tertentu sehingga masyarakat memperoleh pelayanan yang berkualitas, (d) terfokus pada pencapaian visi, misi, tujuan dan sasaran yang berorientasi pada hasil (outcomes) sesuai dengan masukan yang digunakan, (e) lebih mengutamakan apa yang diinginkan oleh masyarakat, (f) memberi akses kepada masyarakat dan responsif terhadap pendapat dari masyarakat tentang pelayanan yang diterimanya, (g) lebih mengutamakan antisipasi terhadap permasalahan pelayanan, (h) lebih mengutamakan desetralisasi dalam pelaksanaan pelayanan, dan (i) menerapkan sistem pasar dalam memberikan pelayanan.

Dalam memenuhi keinginan masyarakat, mengobati patologi birokrasi bisa melalui pembentukan model pelayanan public yang sesuai dengan perkembangan jaman seperti sekarang ini di mana pemerintah berada dalam era desentralisasi.

Model pertama adalah model traditional bureaucratic authority. Ciri dari model ini adalah bahwa pemerintahan daerah bergerak dalam kombinasi tiga faktor yaitu : pertama, penyediaan barang dan layanan publik lebih banyak dilakukan oleh sektor publik (strong public sector). 
Kedua, peran pemerintah daerah sangat kuat (strong local government) karena memiliki cakupan fungsi yang luas, mode operasi yang bersifat mengarahkan, derajat otonomi yang sangat tinggi, dan tingkat kendali eksternal yang rendah.

Ketiga, pengambilan keputusan dalam pemerintah daerah lebih menekankan pada demokrasi perwakilan (representative democracy).

Patologi birokrasi belum didukung teknologi menyeluruh maka perlu ditetapkan sistem teknologi yang Sesuai dengan kebutuhan masyarakat yang makin meningkat, tuntutan yang lebih terbuka, serta perkembangan globalisasi yang memicu peningkatan yang lebih cepat lagi dalam kebutuhan dan tuntutan akan layanan publik, maka model birokrasi tradisional tersebut biasanya dianggap tidak lagi memadai. Untuk itu, diperlukan suatu model baru yang mampu beradaptasi dengan tuntutan perubahan ini. Model yang mampu menyelesaikan berbagai persoalan masyarakat serta merespon berbagai perubahan yang terjadi dengan cepat.

Kata kuncinya adalah Kecamatan Jekan Raya harus melakukan pendekatan organisasi yang profesional, melayani kepentingan masyarakat terutama dalam upaya meningkatkan kualitas pelayanan publiknya, seperti: (a) Model Kelembagaan, (b) Model Pengelolaan Organisasi Pelayanan Publik, (c) Model Siklus Layanan (Momment of Truth), dan (d) Model Standar Pelayanan Minimal. Model-model ini dimaksudkan agar permasalahan pelayanan publik dapat dilakukan dengan baik dan tidak adanya gap-gap.

Upaya mengatasi patologi birokrasi itu sendiri pada hakekatnya adalah pemberian pelayanan prima kepada masyarakat yang merupakan perwujudan kewajiban aparatur pemerintah sebagai abdi masyarakat. Namun kondisi yang terjadi di masyarakat menunjukkan bahwa pelayanan publik dalam bentuk pelayanan administrasi kependudukan belum sepenuhnya berjalan optimal dan masih ditemui hambatan- hambatan dilapangan.
Berdasar dari uraian di atas mempermudah pemahaman masyarakat tentang kondisi pelayanan pada kantor Kecamatan Jekan Raya yang bisa diamati adalah komitmen dari para aparatur untuk melayani masyarakat bersikap adil tanpa melakukan tindakan diskriminatif, selain itu juga adanya kelengkapan sarana dan prasarana yang menunjang kegiatan pelayanan untuk meningkatkan kualitas pelayanan kepada masyarakat, maka upaya-upaya yang dilakukan adalah :

I. Konsolidasi ke dalam

Dalam lingkungan kantor kecamatan

Jekan Raya sendiri dilakukan hal- hal sebagai berikut

a. Mempertegas dan meningkatkan pemahaman dan kesadaran akan tugas pokok atau kewajiban sebagai abdi masyarakat dalam memberikan pelayanan umum sebagai hak masyarakat. Dengan pemahaman seperti ini diharapkan pelayanan yang diberikan tanpa tendesi apa-apa kecuali niat untuk melaksanakan kewajiban sebaik-baiknya. Pada akhirnya diharapkan akan memberikan pelayanan yang betul- betul memuaskan masyarakat.

b. Meningkatkan pemahaman tentang ketentuan pelayanan khususnya menyangkut prosedur dan persyaratan pelayanan yang sesuai dengan peraturan yang berlaku, dengan pemahaman yang baik akan memudahkan dan mempercepat pelaksanaan pelayanan sekaligus membantu apabila mengalami kesulitan tentang masalah pelayanan.

c. Meningkatkan perbaikan sikap aparat dalam melayani. Hal menyangkut kemampuan dan keramahan sikap sebagaimana kodrat manusia yang senang berhubungan dengan orang yang mampu berkomunikasi dengan baik disertai sikap yang ramah demikian pula masyarakat pada umumnya akan sangat 
mengharapkan keramahan sikap dan

komunikasi yang menyenangkan dari aparat pemerintah.

d. Melengkapi fasilitas sarana dan prasarana layanan, dimana kualitas layanan ditentukan oleh kenyamanan yang dirasakan oleh penerima layanan.

2. Konsolidasi keluar

Upaya-upaya yang berkaitan dengan lingkungan luar kantor Kecamatan Jekan Raya yang dalam hal ini adalah masyarakat selaku penerima layanan berkaitan dengan hal tersebut maka aparat pemerintah harus mensosialisaikan peraturan daerah tentang pelayanan kepada masyarakat, peningkatan pelayanan ini baik dari dalam maupun dari luar organisasi, tidak akan efektif tanpa adanya pengawasan yang intensif dari pimpinan. Dalam hal ini untuk meningkatkan kualitas pelayanan dapat tercapai.

Tuntutan pada penguatan kualitas sumber daya manusia dan organisasi secara keseluruhan merupakan perwujudan dan tuntutan kualitas layanan yang diberikan oleh organisasi publik yang semakin baik.

Berdasarkan dari petikan wawancara dengan semua informan di atas dapat kita lihat bahwa secara keseluruhan informan menyatakan pelayanan publik yang ada di Kantor Kecamatan Jekan Raya sudah berlaku adil dalam memberikan pelayanan, tidak membeda-bedakan pelayanan yang diberikan, apapun status sosialnya pelayanan tetap diberikan secara sama sebagaimana mestinya, serta tidak memungut biaya dalam pemberian pelayanan

Seiring dengan semakin tingginya tuntutan publik terhadap kinerja birokrasi, maka posisi strategis aparat pelayan masyarakat dalam organisasi menjadi sangat penting. Dalam hal ini aparatur Kecamatan Jekan Raya harus mampu mendefinisikan persoalan masyarakat dan menghubungkan dengan tugas dan fungsi secara proporsional karena pemerintah kecamatan merupakan unit yang paling dekat dengan masyarakat dan berusaha meningkatkan kualitas pelayanannya dengan mengembangkan unit pelayanan terpadu atau mendelegasikannya mulai dari Kelurahan sampai pada tingkat Kecamatan sehingga prosesnya lebih cepat dan mudah.

Penanganan sikap diskriminatif terhadap pelayanan administrasi kependudukan perlu jalan keluar (solusi) yakni pentingnya keterbukaan suatu birokrasi dalam arti kejelasan peraturan perundang-undangan yang menjadi dasar bertindak, kriteria pemberian pelayanan yang diutamakan serta bentuk pelayanan apa yang harus diberikan. Jika masing-masing pihak taat kepada ketentuan formal dan kriteria yang terpampang dengan jelas, akan semakin tertutuplah kemungkinan bagi aparatur pemerintahan untuk bertindak diskriminatif, suatu perilaku yang memang tidak diharapkan ditampilkan. Apabila terjadi, dampaknya ialah citra birokrasi yang bersangkutan akan ternoda.

3. Meningkatkan Responsivitas

Daya tanggap adalah respon atau kesiapan dalam memberikan pelayanan kepada masyarakat yang cepat dan tanggap, yang meliputi : kesiapan pegawai dalam melayani masyarakat, kecepatan pegawai dalam menangani keluhan masyarakat khususnya masyarakat yang berdomisili di Kecamatan Jekan Raya.

Daya tanggap berkaitan dengan kecepatan dan kesigapan pegawai Dalam memberikan respon terhadap keluhan dari masyarakat. Keluhan dari masyarakat yang membutuhkan pelayanan haruslah direspon dan ditangani dengan cepat dan tepat

Responsivitas diukur tingkat kepekaan pekerjaan dengan hasil yang dicapai, dan prioritas terhadap tugas dan pekerjaan yang mendesak serta 
kesesuaian dengan kebutuhan masyarakat, keinginan para staf untuk membantu masyarakat dan memberikan pelayanan dengan tanggap merupakan salah satu aspek penting dalam memberikan kepuasan kepada masyarakat yang dilayani. Prosedur pelayanan yang harus dilalui setiap orang yang membutuhkan pelayanan pada instansi ini sebenarnya cukup mudah dan sederhana, tidak berbelit-belit, mudah dipahami dan dilaksanakan baik oleh masyarakat yang dilayani maupun petugas yang memberikan pelayanan.

Wujud dari pelaksanaan pelayanan yang perlu diberikan sangat ditentukan oleh sikap, profesi dan respon atas keluhan masyarakat. Daya tanggap yang ditunjukkan kepada warga yaitu :

a. Memberikan informasi yang sesuai kepada masyarakat tentang kapan pelayanan administrasi jasa akan dilaksanakan;

b. Bersedia membantu masyarakat yang kesulitan dalam proses pelayanan;

c. Cepat dalam merespon permintaan masyarakat;

d. Memberikan pelayanan secepatnya kepada masyarakat.

Pegawai memiliki daya respon yang cepat pada setiap masyarakat yang membutuhkan pelayanan baik pelayanan yang berkaitan dengan administrasi maupun pelayanan yang berkaitan dengan pemecahan masalah, hal-hal yang dibutuhkan masyarakat selama ini cukup kompleks tergantung permasalahan apa saja yang dihadapi masyarakat selalu direspon cepat oleh pegawai, seketika itu pula pegawai selalu siap dalam memberikan pelayanan. Daya tanggap dalam melakukan pelayanan publik di Kantor Kecamatan tergantung dari apa saja yang menjadi kebutuhan masyarakat sepanjang permasalahan dan pegawai selalu sigap dalam melakukan pelayanan. Ukuran kinerja pegawai dalam pelayanan publik ada beberapa aspek kualitas layanan, kualitas pelayanan yang diberikan harus dipertahankan dan melaksanakan tugas dan fungsi masing- masing. Selain itu daya tanggap dan responsivitas memiliki kemampuan untuk mengenali kebutuhan masyarakat, pelayanan yang diberikan harus sesuai dengan aturan yang ada.

Solusi yang dihadirkan aparat Kantor Kecamatan Jekan Raya dalam hal pemberian respon adalah bagaimana mempersingkat sistem prosedur pelayanannya serta langsung turun ke lapangan untuk memantau permasalahan yang terjadi yang kemudian akan langsung ditindaki.

4. Penyederhanaan Prosedur Pelayanan yang Transparan

Kejelasan sangat penting dalam pelayanan publik, karena indikator ini dapat mempengaruhi kepercayaan masyarakat terhadap aparatur pemerintah Kecamatan. Pelayanan yang diberikan kepada masyarakat harus sesuai standar operasional pelayanan yang ada. Aparatur Kecamatan telah mengetahui dengan jelas cara pengurusannya, dengan demikian aparatur pemerintah Kecamatan dapat menyelesaikan pekerjaannya dengan baik.

Undang-Undang nomor 25 tahun 2009 tentang pelayanan publik, pada ayat 9 disebutkan bahwa sistem informasi pelayanan publik yang selanjutnya disebut sistem informasi adalah rangkaian kegiatan yang meliputi penyimpanan dan pengelolaan informasi serta mekanisme penyampaian informasi dari penyelenggara kepada masyarakat dan sebaliknya dalam bentuk lisan, tulisan Latin, tulisan dalam huruf Braile, bahasa gambar, dan/ atau bahasa lokal, serta disajikan secara manual ataupun elektronik

Pelayanan pemerintah sebagai pelaku organisasi publik harus bersifat netral dan tidak memihak. Pada dasarnya setiap orang berhak 
mendapatkan kesempatan dan pelayanan yang sama. Hal ini harus perlu dilaksanakan oleh aparatur dalam memberikan pelayanan kepada setiap orang, dengan itu masyarakat akan merasa puas akan pelayanan yang diberikan oleh aparatur pemerintah.

Pelayanan dengan cepat dan tepat sesuai dengan waktu yang telah ditentukan yaitu prosedur/tata cara pengurusan. Pemerintah Kecamatan Jekan Raya sudah berusaha memberikan pelayanan dengan cepat dan tepat kepada masyarakat. Namun ada beberapa masyarakat yang sedikit mengeluh karena harus menunggu dalam proses pelayanan.

Solusi penyelenggaraan pelayanan administrasi kependudukan yang transparan dan partisipatif yakni meningkatkan kualitas pelayanan publik dalam wujud pelayanan yang cepat, mudah, berkeadilan, berkepastian hukum, transparan, aman, tepat, biaya yang wajar, dan dapat dipertanggungjawabkan.

5. Mencegah Praktek Maladministrasi

Praktek maladministrasi merupakan salah bentuk patologi birokrasi yang ada di Indonesia seperti yang telah diuraikan di atas adalah praktek- praktek yang sering terjadi dalam penyelenggaraan pelayanan publik di Indonesia. Sesuai dengan pengalaman yang pernah saya temui, praktek maladministrasi dapat terjadi karena adanya interaksi secara langsung serta diperparah oleh kurang memadainya alat pelayanan yang digunakan dan tidak jelasnya aturan tentang biaya dan waktu untuk pemberian layanan. Membenahi administrasi secara keseluruhan menurut hemat penulis ada tiga hal yang penting sebagai berikut :

a. Adanya reformasi administrasi yang global. Artinya reformasi administrasi bukan hanya sekedar mengganti personil saja, bukan hanya merubah nama intansi tertentu saja, atau bukan hanya mengurangi atau merampingkan birokrasi saja namun juga reformasi yang tidak kasat mata seperti upgrading kualitas birokrat, perbaikan moral, dan merubah cara pandang birokrat, bahwa birokrasi merupakan suatu alat pelayanan publik dan bukan untuk mencari keuntungan.

b. Pembentukan kekuatan hukum dan perundang-undangan yang jelas. Kekuatan hukum sangat berpengaruh pada kejahatan-kejahatan, termasuk kejahatan dan penyakait-penyakit yang ada di dalam birokrasi.

c. Menciptakan sistem akuntabilitas dan transparansi. Kurangnya demokrasi dan rasa bertanggung jawab yang ada dalam birokrasi membuat para birokrat semakin mudah untuk menyeleweng dari hal yang semestinya dilakukan. Pengawasan dari bawah dan dari atas merupakan alat dari penciptaan akuntabilitas dan transparansi ini. Pembentukan E-Government diharapkan mampu menambah transparansi sehingga mampu memperkuat akuntabilitas para birokrat.

Salah satu ciri pelayanan yang akuntabel ialah pelayanan yang memberikan solusi atau jalan keluar bagi setiap warga masyarakat saat mengalami kesulitan. Solusi yang diberikan adalah solusi terbaik bagi pengguna jasa guna kemudahan pelayanan dengan cara memberikan informasi yang dibutuhkan oleh pengguna jasa dan baru segera membantu menyelesaikan, serta tidak menerima pemberian uang ekstra pelayanan.

Budaya pengguna jasa tersebut sangatlah sulit untuk dihilangkan. Alangkah baiknya, jika pengguna jasa ingin memberikan tips, sebaiknya petugas menolaknya dengan berdalih bahwa tindakan tersebut sudah merupakan tugas yang di amanahkan. Untuk itu pemahaman eksistensi birokrasi sebagai abdi masyarakat dan eksistensi masyarakat pengguna jasa sebagai tuan harus 
mendapatkan pelayanan dalam penyelenggaraan publik.

\section{KESIMPULAN}

Berdasar dari bentuk patologi birokrasi yang ditemukan di kantor Kecamatan Jekan Raya yakni sikap I) pelayanan yang bersifat diskriminatif, menunjukkan sikap bahwa kepedulian dimana sebahagian warga sudah puas akan kesamaan dan tidak ada pilih kasih dalam hal pelayanan yang diterima akan tetapi tentunya masih ada yang harus diperbaiki dalam sistem pelayanan tersebut; 2) daya tanggap (responsivitas) aparat terhadap berbagai keluhan yang dialami oleh pengguna layanan, bahkan terkesan segala kritik dan saran yang diarahkan kepada para aparat hanya direspon dengan bahasa-bahasa diplomatis; 3) Pelayanan yang masih berbelit-belit, yang menurut pihak Kecamatan Jekan Raya disebabkan karena masyarakat tidak mengetahui prosedur dan tata cara pengurusan; 4) penyelenggaraan administrasi kependudukan di kantor Kecamatan Jekan Raya bukan hanya disebabkan oleh rendahnya inisiatif para petugas pelayanan, tetapi juga terhambat oleh informasi pejabat untuk mengambil keputusan masih sangat rendah.

Adapun upaya yang dilakukan aparat Pemerintah Kecamatan Jekan Raya dilakukan secara terstruktur yaitu budaya ramah di dalam pelayanan yang berorientasi pemerintah sebagai penyedia terhadap kebutuhan masyarakat sebagai pengguna perlu lebih ditingkatkan lagi dan penting dalam mempengaruhi tingkat kepuasan masyarakat dimana pelayanan yang sifatnya merata dan tanpa membedabedakan status dan kedudukan dimana ditunjang tersedia sarana dan prasarana yang memadai dalam pelayanan administrasi kependudukan, dalam pelayanan yang cepat dan tepat sesuai dengan waktu yang telah ditentukan sehingga dari bentuk dan upaya tersebut diatas disimpulkan bahwa patologi birokrasi harus diobati dengan aturan, sistem dan komitmen pengelolaan yang berorientasi melayani, bukan dilayani, mendorong, bukan menghambat, mempermudah, bukan mempersulit, sederhana, bukan berbelit-belit, terbuka untuk setiap orang, bukan hanya untuk segelintir orang.

Sehingga Perlunya perbaikan pelayanan administrasi kependudukan untuk meningkatkan pelayanan yang optimal kepada masyarakat, seperti upaya penambahan sarana dan prasarana (komputer, mesin cetak,dan lain-lain). Kemudian, Sebaiknya pihak Pemerintah Kecamatan Jekan Raya dapat menyebarluaskan brosur tentang Standar Operasional Pelayanan agar masyarakat mengetahui prosedur pengurusannya dan agar tidak menimbulkan kesan yang berbelit-belit. Serta Pemerintah Kecamatan Jekan Raya dapat memberikan informasi kepada masyarakat untuk menyampaikan atau memberikan surat apabila ada keluhan-keluhan di kotak/loket yang telah disediakan. Hal ini dimaksudkan agar para pegawai dapat mengevaluasi kekurangankekurangan dan terus meningkatkan kualitas pelayanan dalam meningkatkan kepuasan pada masyarakat.

\section{REFERENSI}

Dwiyanto, Agus. dkk. 2003. Reformasi Tata Pemerintahan dan Otonomi Daerah, Yogyakarta: Pusat Studi Kependudukan dan Kebijakan Universitas Gajah Mada.

Kusdarini, Eny. 201I. Dasar-Dasar Hukum Administrasi Negara dan Asas-Asas Umum Pemerintahan yang Baik. Yogyakarta: UNY Press.

Moenir, H.A.S . 2002. Manajemen Pelayanan Umum di Indonesia. Jakarta : Bumi Aksara.

Istianto, Bambang. 20II. Demokratisasi Birokrasi. Jakarta: Mitra Wacana Media.

Sinambela, Litjan Poltak dkk. 20I I. Reformasi Pelayanan Publik Teori, Kebijakan, Implementasi. Jakarta: Bumi Aksara. 
Kusdi. 2009. Teori Organisasi dan Administrasi. Jakarta: Salemba Humanika

Margono. 2004. Metodologi Penelitian Pendidikan, Jakarta: PT. Rineka Cipta

Ratminto dan Atik Septi Winarsih. 2006.

Manajemen Pelayanan. Yogyakarta : Pustaka

Pelajar.

Thoha, Miftah. 2002. Dimensi-dimensi Prima Ilmu Administrasi Negara. Jakarta : PT. Raja Grafindo Persada.

2005. Birokrasi Politik di Indonesia.

Jakarta : PT. Raja Grafindo Persada.

---,2008. Birokrasi Pemerintah Indonesia di Era

Reformasi. Jakarta: Kencana

\section{Perundang-Undangan}

Undang-Undang Republik Indonesia Nomor. 37

Tahun 2008 Tentang Ombudsman

Undang-Undang Republik Indonesia Nomor 14

Tahun 2008 Tentang Keterbukaan Informasi

Publik

Undang-Undang Republik Indonesia Nomor 25

Tahun 2009 Tentang Pelayanan Publik

Undang-Undang Republik Indonesia Nomor 5

Tahun 2014 tentang Aparatur Sipil Negara

Keputusan MENPAN No.63/KEP/MENPAN/7/2003

Tentang Pedoman Umum Penyelenggaraan

Pelayanan Publik

Peraturan Menteri Pendayagunaan Aparatur Negara dan Reformasi Birokrasi Nomor No. 35 tahun

2006 tentang Pedoman Penyusunan Standar

Operasional Prosedur (SOP) Administrasi

Pemerintah

Peraturan Walikota Palangka Raya Nomor 14 Tahun

2015 tentang Retribusi Pelayanan Administrasi

Kependudukan dan Pencatatan Sipil 